\title{
Determination of Structure and Properties of Modified Chlorophylls by Using Fast Atom Bombardment Combined with Tandem Mass Spectrometry
}

\author{
Richard P. Grese, Ronald L. Cerny, and Michael L. Gross \\ Midwest Center for Mnss Spectrometry, Department of Chemistry, University of Nebraska-Lincoln, \\ Lincoln, Nebraska, USA \\ Mathias Senge \\ Fachbereich Biologie-Botanik der Philipps-Universität, D-3550 Marburg, Federal Republic of Germany
}

\begin{abstract}
Tandem mass spectrometry (MS/MS) was used to investigate and compare the decompositions of radical cations $\left(\mathrm{M}^{+}\right)$, radical anions $\left(\mathrm{M}^{-}\right),[\mathrm{M}+\mathrm{H}]^{+}$ions, and $[\mathrm{M}+\mathrm{Cat}]^{+}$ions (Cat = alkali metal ions) of chlorophylls. Included in this study are chlorophyll $a$, chlorophyll $b$, bacteriochlorophyll $a$, chlorophyll $a$ allomers, and the corresponding pheophytins. Fast atom bombardment of chlorophyll a produces abundant $\mathrm{M}^{+\cdot}$ ions, which decompose metastably and upon collisional activation to give fragment ions from losses of the phytyl chain and the $\beta$-keto group of ring V. In addition, previously unreported charge-remote fragmentations are useful for identification of branch points on the phytyl chain. Collisional activation of $\left[\mathrm{M}+\mathrm{Cat}^{+}\right.$ions produces fragment ions that are complementary to those of the $\mathrm{M}^{+\cdot}$ and are used to examine the intrinsic gas-phase reactivity of metal ions and chlorophylls. Peripheral metal ion attachment in chlorophyll $a$ in the gas phase is suggested to be at C-9, and the $\beta$-keto ester group at C-10, of ring V. Examination of decompositions of chlorophyll dimers suggests that in the gas phase the interaction between monomers involves bonding of the $\mathrm{Mg}$ atom of one chlorophyll a molecule and the C-9 carbonyl oxygen of the other, which was also suggested for chlorophyll a dimers in solution. (J Am Soc Mass Spectrom 1990, 1, 72-84)
\end{abstract}

$\mathrm{T}$ The importance of chlorophylls in photosynthesis has encouraged their study since early in the nineteenth century [1]. The structures of chlorophyll $a$ (chl $a$ ) 1a and chlorophyll $b$ (chl $b$ ) 2a have long been established; however, questions that pertain to their biosynthesis, aggregation, and reactivity and the structures of chemically modified chlorophylls still present an analytical challenge.

Improved methods for structural determinations are needed to elucidate further chlorophyll biosynthesis and photosynthetic mechanisms. For example, recent results indicate that the biosynthesis of chl $a$ is not straightforward, and several novel chlorophyll intermediates have been predicted [2]. In addition, it was shown that certain strains of bacteria, after mutation, possess structurally modified chlorophylls that still function efficiently in photosynthesis [3]. It was demonstrated recently that certain strains of green sulfur bacteria produce methylated bacteriochlorophyll in response to reduced availability of light [4].

Address reprint requests to Michael L. Gross, Department of Chemistry, University of Nebraska, Lincoln, NE 68588-0304.
The chlorophylls, because of their involatility and thermal instability, were not amenable to mass spectrometric analysis until the development of desorption methods. Mass spectra of chl $a$ have been obtained using field desorption [5], ${ }^{252} \mathrm{Cf}$ plasma desorption mass spectrometry (PDMS) [6, 7], laser desorption (LD) [8-10], laser desorption combined with multiphoton ionization (LD/MPI) [11], "in-beam" electron ionization [12], and fast atom bombardment (FAB) $[13,14]$. Very recently, a new method, spontaneous desorption mass spectrometry (SDMS), was used to generate the regative ion spectrum of chl $a$ [15].

We recently reinvestigated the advantages of FAB for the analysis of chlorophyll [16]. We propose that the "explosive" fragmentation observed in PDMS and LD may be due in part to the desorption process and not to the intrinsic fragility of the chl a molecule. In FAB, the liquid matrix acts to modify the strong aggregate interaction of chl $a$ in thin films; thus chl $a$ is desorbed with less internal energy and less fragmentation.

Although FAB/MS is an established method for characterizing biomolecules [17], the lack of fragmen- 

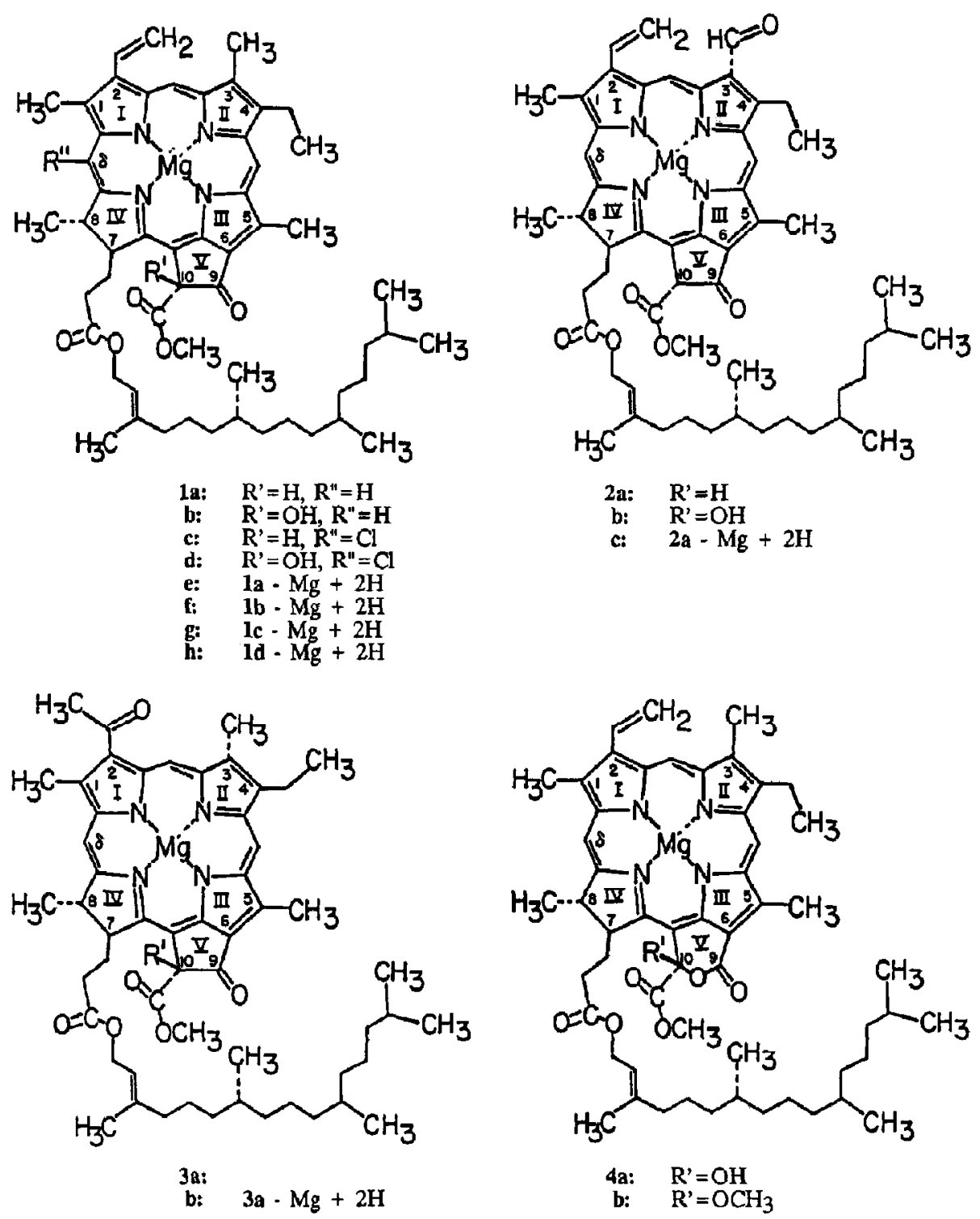

Figure 1. Structures of $\operatorname{chl} a 1, \operatorname{chl} b 2, b c h l a 3$, and lactone chl a 4 derivatives.

tation, the presence of matrix-related chemical noise, and the difficulties in analyzing mixtures are disadvantages often associated with the application of FAB/MS to biological samples. Because of these problems, the combination of $\mathrm{FAB}$ with collisional activation tandem mass spectrometry (MS/CA/MS) is becoming the method of choice for determining a wide variety of biomolecules [18] such as peptides [19], fatty acids [20], nucleosides and nucleotides [21], and steroids [22]. Tandem mass spectrometry (MS/MS) has the potential for providing structural information on samples of limited quantity without exhaustive sample preparation. In addition, it provides confirmation of components in mixtures by providing unambiguous fragmentation information for mass-selected precursor ions.
The first MSiMS study of pheophytin a was carried out by Jackson [23] ten years ago. Molecular ions were generated by ficld desorption, and a magnetic sector mass spectrometer (EB geometry) was used in the linked scan (constant $B / E$ ) mode to observe collisionally activated and metastable decompositions occurring in the first field-free region of the instrument. Only limited results were given, however. Fragment ions arising from losses of the phytyl group and other side chains demonstrate that collisional activation (CA) and metastable ion studies can provide useful structural information.

The CA mass spectrum of chl a was also reported $[24,25]$. These reports dealt with the CA process and did not address the usefulness of FAB/MS/CA/MS for 
structural determinations. In the initial work, the translational energy loss $(\Delta E)$ for the major fragmentation pathway of the chl $a[\mathrm{M}+\mathrm{H}]^{+}$ion $(m / z 893 \rightarrow m / z 614)$ was studied with different collision gases [24]. These experiments point to ionization of the target gas as competitive with CA of the precursor ion. Recently, this work was reinvestigated by others, and no correlation between translational energy loss of the chl $a$ system (either $\mathrm{M}^{+\cdot}$ or $[\mathrm{M}+\mathrm{H}]^{+}$) and ionization of the target gas ionization was found [25].

We present here the first application of FAB/MS/CA/MS to the study of a series of structurally modified chlorophylls. To evaluate MS/MS, we chose chl $a$ 1a, chl $b$ 2a, bacteriochlorophyll $a$ (bchl $a$ ) 3a, chl $a$ allomers (10-hydroxy 1b, 2b, 10-hydroxylactone $4 a$, and methoxylactone $4 \mathrm{~b}$ derivatives), and the corresponding $\mathrm{Mg}$-free analogs, the pheophytins $1 \mathbf{e}-\mathbf{h}, \mathbf{2 c}$, $3 \mathrm{~b}$ as model systems (see Figure 1). We also include the chlorinated chlorophylls, $\delta$-Cl-chl $a \mathbf{1 c}$ and $\delta$-Cl-10$\mathrm{OH}$-chl $a$ [chl $a$ reaction center $\mathrm{I}(\mathrm{RCl})] \mathrm{1d}$. Chlorophyll a $\mathrm{RCI}$, once thought to be important in the photosynthesis reaction center, was recently shown to be an artifact from purification using silica thin-layer chromatography [26].

We will use MS/MS to investigate and then compare the decompositions of radical cations $\left(\mathrm{M}^{+}\right)$, radical anions $\left(\mathrm{M}^{-}\right),[\mathrm{M}+\mathrm{H}]^{+}$, and $\left[\mathrm{M}+\mathrm{Cat}^{+}\right.$(Cat = alkali metal ions) of chlorophylls. In addition, the potential of MS/MS for studying the intrinsic gas-phase reactivities of chlorophylls with alkali metal ions and chlorophyll dimerization will be investigated. The study of chlorophyll dimers may be particularly important because of their role as the "special pair" in the photosynthesis reaction center [27].

Studies of gas-phase cationized species can be useful for assigning the intrinsic reactivity of metal ions and biomolecules and as a source of structural information. FAB/MS/CA/MS was recently used in studies of fatty alcohols and acids [28], sugars [29], alkylsulfonates [30], bile salts [31], peptides [32], and modified nucleosides and nucleotides [33]. In solution, peripheral metal ion attachment in chlorophyll was shown to be associated with the enol formation at C-9 of ring V. and complexation occurs with the $\beta$-keto ester group at C-10 [34]. We expect that the decomposition reactions of chlorophyll-metal ion complexes in the gas phase will reflect the intrinsic interaction of the metal ion and chlorophyll. A precedent is our recent investigation of the gas-phase interactions of alkali metal ions and peptides by using FAB and MS/MS [32a].

\section{Experimental}

\section{Reagents and Procedures}

Chlorophyll $a$ 1a and chlorophyll $b$ 2a were isolated from Scenedesmus obliquus WT- $\mathrm{D}_{3}$ by using standard methods [26b]. Bacteriochlorophyll $a 3 a$ and additional samples of chl $a$ and chl $b$ were obtained from Sigma Chemical Co. (St. Louis, MO). $\delta$-Chloro-chl $a$ 1c was prepared by enzymatic chlorination of chl $a$ with chloroperoxidase [35]. The C-10 hydroxylated chlorophylls 1b, 1d, 2b were prepared by using the method of Pennington et al. [36] or by subjecting the nonhydroxylated precursor compounds to aerobic silica gel thin-layer chromatography [37]. The hydroxylactone $4 a$ and methoxylactone $\mathbf{4 b}$ derivatives were obtained as side products from these procedures. The pheophytins 1e-h, 2c, $3 \mathbf{b}$ were prepared by demetalation of the chlorophylls [38]. The chlorophylls were separated and purified by reverse-phase HPLC.

3-Nitrobenzyl alcohol (3-NBA), o-nitrophenyloctyl ether (ONPOE), glycerol, thioglycerol, and the alkali iodides were obtained from Aldrich Chemical Co. (Milwaukee, WI). The 3-NBA-alkali iodide matrix was prepared by saturating the liquid with the alkali iodide. The DTT/DTE matrix was prepared by heating at $40^{\circ} \mathrm{C}$ and mixing $25 \mathrm{~g}$ of dithiothreitol with $5 \mathrm{~g}$ of dithioerythritol ( $>97 \%$, Aldrich).

For FAB/MS/MS experiments, 0.1-1 $\mu \mathrm{g}$ of chlorophyll was mixed on a copper probe tip with either 3-NBA for production of $\mathrm{M}^{+-}$ions or 3-NBA and alkali iodide for production of $\left[\mathrm{M}+\mathrm{Cat}^{+}\right.$ions.

\section{Instrumentation}

Collisional activation and metastable ion mass spectra were obtained by using a Kratos MS-50 tripleanalyzer mass spectrometer of EB/E design, which was previously described [39]. MS-I is a standard highresolution Kratos MS-50 (ESA and magnet). MS-II is a second electrostatic analyzer (ESA-II). Field-free regions (FFR) in this instrument are located between the source and ESA-I (first FFR), between ESA-I and the magnet (second FFR), and between the magnet and ESA-II (third FFR). The triple-analyzer instrument was equipped with a commercial Kratos FAB source and an Ion Tech saddle-field atom gun (Ion Tech, Middlesex, England).

For FAB/MS/MS experiments, ions were produced by bombarding the sample with 7-8-keV argon atoms and then accelerated through a potential of $8 \mathrm{kV}$. Ions of interest were selected by using MS-I at a mass resolution of approximately 2000 (width at $10 \%$ height). Mass-selected ion kinetic energy-analyzed spectra (MIKES) were obtained by scanning MS-II and then averaging 20 scans by using software written in this laboratory. Collisional activation experiments were done by activating the mass-selected ion with helium in the third FFR with a helium pressure that gave a $50 \%$ main beam suppression.

Accurate mass measurements in FAB/MS experiments were made at a resolution of 10,000 by peak matching to appropriate CsI/glycerol reference ions.

For MS/MS/MS experiments [40], all sourceproduced ions were activated in the first FFR. The fragment ion of interest was then transmitted to the third FFR by setting both ESA-I and the magnet at $m_{2} / m_{1}$ of $B_{0}$ and $E_{0}$, where $m_{1}$ and $m_{2}$ are the precursor and product ion masses, respectively, and $B_{0}$ and $E_{0}$ are 


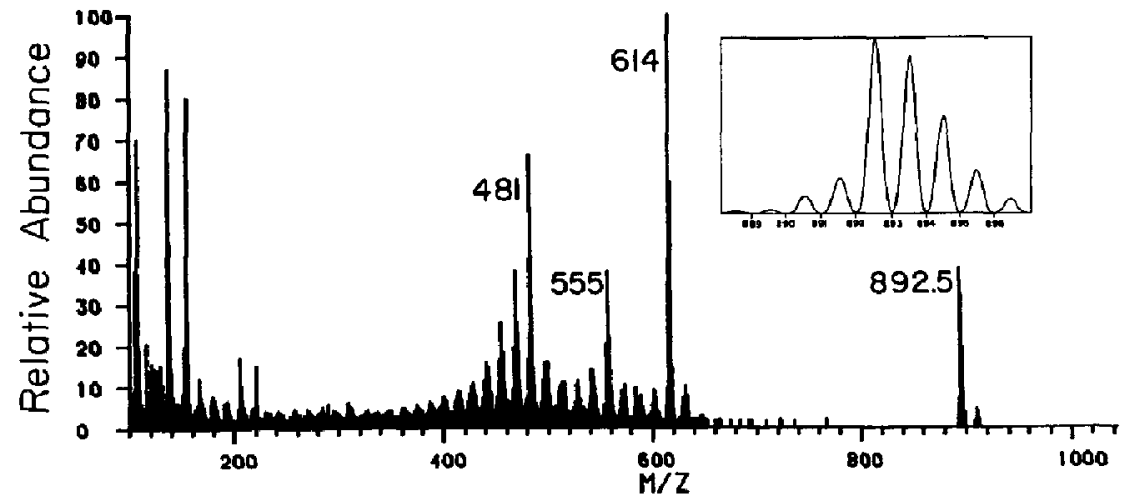

Figure 2. Fast atom bombardment low-resolution mass spectrum of chl a desorbed from a 3-NBA matrix. Inset: Narrow-scan FAB mass spectrum of the molecular ion region $\mathrm{m} / \mathrm{z} 888-897$.

the magnetic and electric field values necessary to focus the main beam. The selected product ion was collisionally activated, and the resultant fragment ions were analyzed by scanning ESA-II.

For linked scans at constant $B / E$, source-produced ions were activated in the first FFR. ESA-I and the magnet were scanned at a constant $B / E$ value determined by the ratio of the field strengths necessary to transmit precursor ions of the desired $m / z$ ratio holding the accelerating potential $(V)$ constant. Fragmentations occurring in the first FFR were observed in this way. The value of ESA-II followed that of ESA-I and the final detector (after ESA-II) was used.

\section{Results and Discussion}

\section{Desorption of Chlorophyll a by Fast Atom Bombardment}

The advantage of using a triple-analyzer mass spectrometer for MS/MS studies is that the precursor ion can be selected at high mass resolution to eliminate contributions from interferences present at the same nominal mass [39]. In these experiments, however, the resolution of MS-I is not sufficient to select unambiguously molecular ions of a single atomic composition of chl $a$.
Fast atom bombardment of chl a $1 \mathrm{a}$ in a matrix of 3-NBA produces an abundant cluster of molecular ions (Figure 2). Comparison of the molecular ion region at a resolution of 2000 with that calculated by considering isotopic abundances indicates that a mixture of molecular species $\left([\mathbf{M}-\mathbf{H}]^{+}, \mathbf{M}^{+}\right.$, and $\left.[\mathrm{M}+\mathrm{H}]^{+}\right)$are generated by FAB. By assuming that the ion of $m / z 891.5$ is composed solely of the $[\mathrm{M}-\mathrm{H}]^{+}$ion (no contribution from the ${ }^{13} \mathrm{C}$ isotope of the $[\mathrm{M}-2 \mathrm{H}]^{+\cdot}$ ion and corrected for matrix background), the molecular ion cluster is calculated to be a mixture of $71 \% \mathrm{M}^{+}, 21 \%$ $[\mathrm{M}+\mathrm{H}]^{+}$, and $8 \%[\mathrm{M}-\mathrm{H}]^{+}$ions (see Table 1 ).

The mass resolution necessary to separate the $\mathrm{M}^{+}$. ion $\left(\mathrm{m} / \mathrm{z}\right.$ 892.5353) from the $[\mathrm{M}-\mathrm{H}]^{+}$ion containing one ${ }^{13} \mathrm{C}$ atom $(\mathrm{m} / \mathrm{z} 892.5308)$ or the $[\mathrm{M}+\mathrm{H}]^{+}$ion ( $m / z$ 893.5431) from the $\mathrm{M}^{+}$isotope containing one ${ }^{13} \mathrm{C}$ atom ( $\left.\mathrm{m} / \mathrm{z} 893.5387\right)$ is 200,000 . This resolution is beyond the resolving capability of our instrument. In these experiments, a resolution of 2000 was used; thus the species selected at $\mathrm{m} / \mathrm{z} 892.5$ is a mixture of $86 \%$ $\mathrm{M}^{+\cdot}$ (all low-mass isotopes) and $14 \%[\mathrm{M}-\mathrm{H}]^{+}$containing one ${ }^{13} \mathrm{C}$ atom. These ratios are similar to those of other chlorophylls and pheophytins desorbed by FAB in this study.

By using slightly acidic matrices (i.e., DTT/DTE, thioglycerol), we were able to increase the amount of the protonated species with respect to the radical

Table 1. Comparison of relative abundances of chlorophyll $a$ molecule ions with calculated values

\begin{tabular}{|c|c|c|c|c|c|}
\hline$m / 2$ & $\begin{array}{l}\text { Calculated } \\
100 \% \mathrm{M}^{+}\end{array}$ & $\begin{array}{c}\text { Calculated } \\
71 \% \mathrm{M}^{+} \\
20 \%[\mathrm{M}+\mathrm{H}]^{+} \\
8 \%[\mathrm{M}-\mathrm{H}]^{+}\end{array}$ & $\begin{array}{l}\text { Position ion } \\
\text { (3-NBA) }\end{array}$ & $\begin{array}{l}\text { Positive ion } \\
\text { (DT/DTE) }\end{array}$ & $\begin{array}{c}\text { Negative ion } \\
(3-N B A)\end{array}$ \\
\hline 890.5 & & & 8.9 & 5.0 & 10.3 \\
\hline 891.5 & & 18.5 & 18.5 & 15.5 & 19.0 \\
\hline 892.5 & 100 & 100 & 100 & 100 & 100 \\
\hline 893.5 & 77.7 & 93.5 & 93.5 & 148 & 76.5 \\
\hline 894.5 & 44.2 & 55.5 & 54.8 & 99.4 & 45.2 \\
\hline 895.5 & 16.9 & 23.7 & 23.4 & 59.9 & 16.7 \\
\hline 896.5 & 4.5 & 7.1 & 6.5 & 25.1 & 5.6 \\
\hline
\end{tabular}


cation. This is in agreement with the work of Brereton et al. [14], who reported a molecular ion cluster composed of an equal mixture of $\mathrm{M}^{+\cdot}$ and $[\mathrm{M}+\mathrm{H}]^{+}$. for a novel chlorophyll desorbed by FAB from thiodiglycol $\left(2,2^{\prime}\right.$-thio-bis-ethanol). The use of highly acidic matrices (e.g., 3-NBA containing heptafluorobutyric acid) leads to elimination of the central $\mathrm{Mg}$ atom and formation of pheophytin on the FAB probe. A comparison of the relative abundances of ions in the molecular ion region of chl $a$ desorbed from DTT/DTE by FAB with theoretical values is provided in Table 1. Calculation of the species that comprise the ions of $\mathrm{m} / \mathrm{z} 893.5 \mathrm{in}$ dicates a mixture of $50 \%[\mathrm{M}+\mathrm{H}]^{+}$(ions containing all ${ }^{12} \mathrm{C}$ atoms), $45 \% \mathrm{M}^{+\cdot}$ containing one ${ }^{13} \mathrm{C}$ (or one ${ }^{25} \mathrm{Mg}$ ) atom, and $5 \%[\mathrm{M}-\mathrm{H}]^{+}$containing two ${ }^{13} \mathrm{C}$ atoms.

The predominance of the radical cation species generated by FAB is not unexpected considering the delocalized $\pi$-system of the chlorin ring and the wellknown photobiochemical properties of chlorophyll. The radical cation of chl $a$ has been formed in solution [41]. The $\mathrm{M}^{+*}$ ion in the mass spectrometry experiments may also form in solution by FAB-induced oxidation. During the FAB experiment, the relative abundances of the oxidation products of chl a (10-hydroxy and 10-hydroxylactone chl $a$ ) and chl $a$-matrix adducts increase with continued bombardment of the sample [16]. In solution, these products are thought to be formed by nucleophilic attack on the chlorophyll radical cation $\left(\mathrm{M}^{+}\right)[42,43]$. These observations are consistent with the formation of the radical cation in solution by FAB-induced oxidation.

\section{Collision-Activated Decomposition of $\mathrm{M}^{+\cdot}$ of Chlorophylls}

The CA mass spectrum of chl $a \mathrm{M}^{+\cdot}$ of $m / z 892.5$ is reporled in Figure 3a. The propused assignments of the most abundant ions are listed in Table 2.

Product ions in the range $m / z$ 400-620 formed upon $C A$ are similar in mass to source-produced fragment ions, which are seen in the full-scan spectrum (Figure 2). The CA spectrum, however, is less ambiguous because only the decompositions of the ions of a single nominal mass (predominantly the $\mathrm{M}^{+\cdot}$ species) are measured. The substantial energy loss accompanying CA with helium [44] limits the accuracy of mass assignments in the MS/CA/MS spectra. Mass assignments, therefore, were confirmed by comparison of the $C A$ mass spectra with metastable ion spectra obtained in the same mode, CA mass spectra using argon as target gas, and CA $B / E$ linked scan spectra. The energy loss accompanying $\mathrm{CA}$ with helium associated with the ion of miz 614 was calculated by using the method of Cooks [45] to be $23.4 \pm 0.1 \mathrm{eV}$, which is in good agreement with the value reported by Bricker and Russell [24] and Boyd et al. [25].

The product ion of $\mathrm{m} / \mathrm{z} 614$ results from cleaving off the phytyl chain with a hydrogen transfer back to the ion to produce the carboxylic acid. Highresolution mass analysis of the ion of $m / z 614$ produced

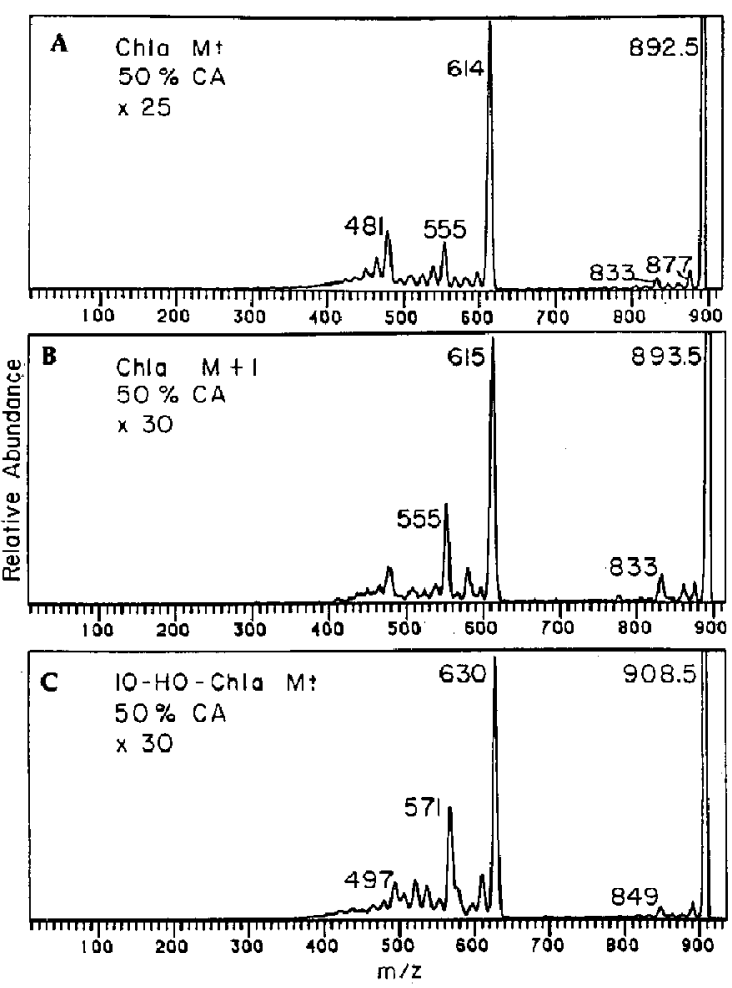

Figure 3. Collisional activation mass spectra of (a) chl $a_{r}$ ions of $\mathrm{m} / \mathrm{z} 892.5$ (mixture of $86 \% \mathrm{M}^{+}$and $14 \%{ }^{13} \mathrm{C}$ of $[\mathrm{M}-\mathrm{H}]^{+}$); (b) chl $a$, ions of $\mathrm{m} / \mathrm{z} 893.5$ (mixture of $50 \%[\mathrm{M}+\mathrm{H}]^{+}, 45 \%{ }^{13} \mathrm{C}$ of $\mathrm{M}^{+}$, and $5 \%[\mathrm{M}-\mathrm{H}]^{+}$containing two ${ }^{13} \mathrm{C}$ ); and (c) 10-hydroxy chl $a, \mathrm{M}^{+\cdot}$ ion of $m / z$ 908.5.

in the FAB source indicates an atomic composition of $\mathrm{C}_{35} \mathrm{H}_{34} \mathrm{~N}_{4} \mathrm{O}_{5} \mathrm{Mg}$ (measured mass within 2 ppm deviation from that of the calculated mass of $614.2380 \mathrm{u}$ ), which is consistent with this structure. This ion is also the most abundant fragment ion in the metastable ion spectrum. Less abundant ions of $m / z 555,481$, and 467 are probably due to subsequent losses from the ion of $\mathrm{m} / \mathrm{z}$ 614. Scheme I depicts possible pathways for the formation of the product ions and was originally proposed by Chait and Field [7]. Collision-activated decomposition (CAD) of the source-produced fragment

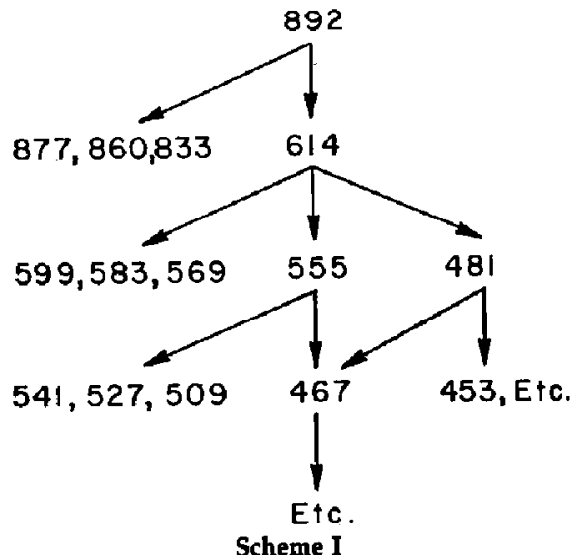

Scheme I 
Table 2. Collisional activation mass spectrum of chlorophyll $a \mathrm{M}^{+}$.

\begin{tabular}{|c|c|c|}
\hline$m / z$ & Relative abundance & Assignment \\
\hline 892 & & $M^{+*}$ \\
\hline 877 & 3 & {$\left[\mathrm{M}-\cdot \mathrm{CH}_{3}\right]^{+}$} \\
\hline 860 & 2 & {$\left[\mathrm{M}-\mathrm{CH}_{3} \mathrm{OH}\right]^{+\cdot}$} \\
\hline 833 & 2 & {$\left[\mathrm{M}-\cdot \mathrm{COOCH}_{3}\right]^{+}$} \\
\hline 614 & 100 & {$\left[\mathrm{M}-\mathrm{C}_{2 \mathrm{D}} \mathrm{H}_{38}\right]^{+}$} \\
\hline 599 & 4 & {$\left[\mathrm{M}-\mathrm{C}_{20} \mathrm{H}_{38}-\cdot \mathrm{CH}_{3}\right]^{+}$} \\
\hline 583 & 5 & {$\left[\mathrm{M}-\mathrm{C}_{29} \mathrm{H}_{38}-\mathrm{HOCH}_{3}\right]^{+}$} \\
\hline 569 & 4 & {$\left[\mathrm{M}-\mathrm{C}_{20} \mathrm{H}_{38}-\cdot \mathrm{COOH}\right]^{+}$} \\
\hline 555 & 16 & {$\left[\mathrm{M}-\mathrm{C}_{20} \mathrm{H}_{38}-\cdot \mathrm{COOCH}_{3}\right]^{+}$or $\left[\mathrm{M}-\cdot \mathrm{CH}_{2} \mathrm{COOC}_{20} \mathrm{H}_{39}\right]^{+}$} \\
\hline 540 & 7 & {$\left[\mathrm{M}-\cdot \mathrm{CH}_{2} \mathrm{CH}_{2} \mathrm{COOC}_{20} \mathrm{H}_{39}\right]^{+}$} \\
\hline 527 & 4 & \\
\hline 509 & 6 & \\
\hline 495 & 3 & {$\left[\mathrm{M}-\cdot \mathrm{CH}_{2} \mathrm{COOC}_{20} \mathrm{H}_{39}-\mathrm{CO}-\mathrm{HOCH}_{3}\right]^{+}$} \\
\hline 481 & 27 & $\left.\mathrm{IM}-\cdot \mathrm{CH}_{2} \mathrm{CH}_{2} \mathrm{COOC}_{20} \mathrm{H}_{39}-\mathrm{CO}-\mathrm{HOCH}_{3}\right]^{+}$ \\
\hline 467 & 10 & {$\left[\mathrm{M}-\cdot \mathrm{CH}_{2} \mathrm{CH}_{2} \mathrm{COOC}_{20} \mathrm{H}_{3 \mathrm{~g}}-\mathrm{CO}-\mathrm{HOCH}{ }_{3}-14\right]^{+}$} \\
\hline 453 & 7 & \\
\hline 439 & 4 & \\
\hline
\end{tabular}

ions of $m / z 614,555$, and 481. (Figure 4a-c) supports this mechanism. Collision-activated decompositions of the $m / z 614$ ion in MS/MS/MS experiments are also consistent with this fragmentation scheme and similar to those reported in Figure 4c.

Of special interest are the less abundant ions of $m / z>620$, which have not been previously reported. Figure 5 is the CA mass spectrum of pheophytin a 1e, which is representative also of the chlorophylls. A series of regularly spaced peaks separated by $14 \mathrm{u}$ are assigned to losses of the elements of $\mathrm{C}_{n} \mathrm{H}_{2 n+2}$ (i.e., $\mathrm{CH}_{4}, \mathrm{C}_{3} \mathrm{H}_{8}$, etc.) produced by charge-remote fragmentation of the phytyl chain. Branch points in the phytyl chain are identified by interruptions in the series of alkane losses. Similar charge-remote fragmentations

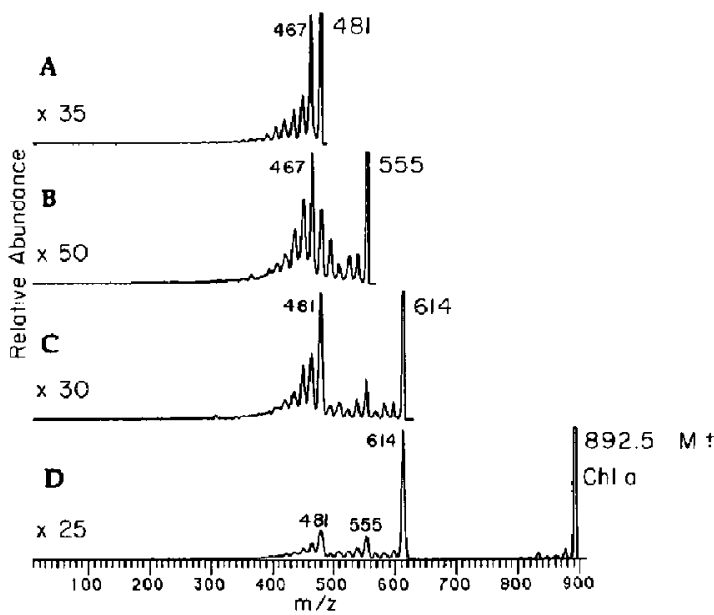

Figure 4. (a-c) Collisional activation mass spectra of FAB sourceformed fragment ions of chl a of (a) $\mathrm{m} / \mathrm{z}$ 614, (b) $\mathrm{m} / \mathrm{z} 555$, (c) $\mathrm{m} / \mathrm{z}$ 481. (d) Collisional activation mass spectrum of chl $a$ molecular ion $\left(\mathrm{M}^{+}\right)$of $m / z 892.5$. apply to the CAD of carboxylate anions of fatty acids [46], alkali metal cationized fatty alcohols and acids [28], and protonated piconyl ester derivatives of fatty acids [47]. These fragmentations confirm the structure of the phytyl chain and provide the possibility of easily determining the structure of other chains that are not phytyl esters in novel chlorophylls without resorting to chemical hydrolysis and subsequent analysis of the saponified alcohol [48].

These charge-remote fragmentations are more evident in the CA mass spectra of the pheophytins. Thus, it is analytically useful to produce the pheophytins from the chlorophylls on the FAB probe tip by addition of heptafluorobutyric acid (HFBA), as mentioned earlier.

The ions of $m / z 838$ and 811 (Figure 5) are not associated with fragmentation of the phytyl chain (similar ions in the chl a spectrum are at $m / z 860$ and 833). These two ions are due to fragmentation of the $\beta$-keto ester group of ring $V$. The ion of $m / z 838$ is proposed

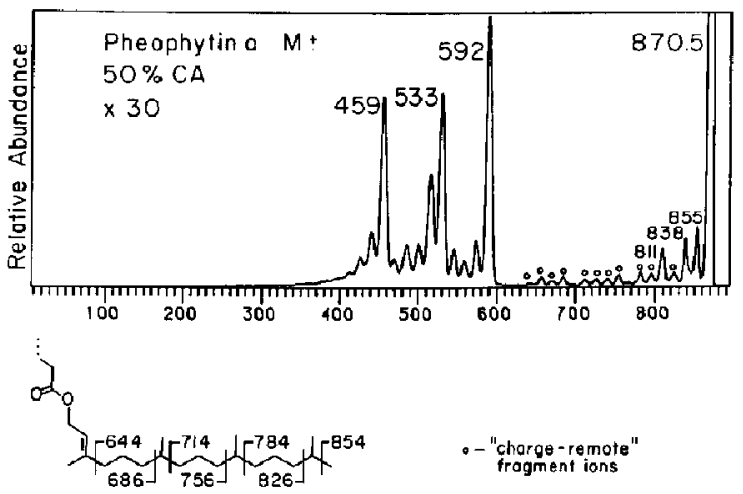

Figure 5. Collisional activation mass spectra of pheophytin a $\mathrm{M}^{+\cdot}$ ion of $m / z 870.5$. 


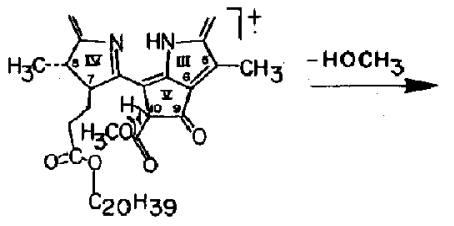

Scheme II

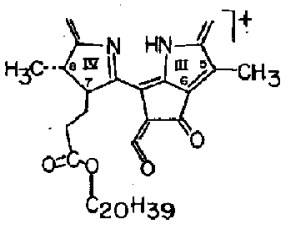

$\underline{m} / \underline{z} \quad 838$

to be formed by loss of methanol and formation of the stable ketene ion, as previously reported (Scheme II) [49]. The loss of methanol is not seen upon CA of the chlorophyll derivatives in which the $\mathrm{C}-10$ hydrogen is replaced by a hydrexy group $\mathbf{1 b}, \mathbf{1 d}, \mathbf{1 f}, \mathbf{1 h}, \mathbf{2 b}$ (Figure 3c). This is further evidence for the mechanism and provides a simple way to determine the presence or absence of a substituent other than $\mathrm{H}$ at $\mathrm{C}-10$. The ion of $\mathrm{m} / z \mathrm{z} 11$ arises by a simple cleaving off of the C-10 ester group $\left(\cdot \mathrm{COOCH}_{3}\right)$ and is an abundant ion for all the chlorophylls studied.

Generally, the CAD of the $\mathrm{M}^{+\cdot}$ of the other chlorophylls and pheophytins studied here are similar to that of chl $a$. The loss of the phytyl chain gives the most abundant fragment ion for all the compounds; there are slight differences, however, in the relative abundances of several other fragment ions. For example, the ion from the loss of $337 \mathrm{u}\left(\left[\mathrm{M}-\mathrm{C}_{20} \mathrm{H}_{38}-\right.\right.$ . $\left.\mathrm{COOCH}_{3}\right]^{+}$or $\left.\left[\mathrm{M}-\cdot \mathrm{CH}_{2} \mathrm{COOC}_{20} \mathrm{H}_{39}\right]^{+}\right)$is more abundant in the CAD of hydroxy chl a 1c (Figure 3c) than of chl $a$ 1a; the ion formed by the loss of $411 \mathrm{u}$ $\left(\left[\mathrm{M}-\cdot \mathrm{CH}_{2} \mathrm{CH}_{2} \mathrm{COOC}_{20} \mathrm{H}_{39}-\mathrm{CO}-\mathrm{HOCH}_{3}\right]^{+}\right)$, however, is more abundant for chl $a$. The CA mass spectrum of $\delta-\mathrm{Cl}-\mathrm{chl} a$ is qualitatively similar to that of chl $a$; likewise, the CA mass spectrum of $\delta$-Cl-10-OH-chl $a$ is qualitatively similar to that of $10-\mathrm{OH}-\mathrm{chl} a$. Loss of $\mathrm{HCl}$ from $\delta-\mathrm{Cl}-\mathrm{chl} a$ and $10-\mathrm{OH}-\mathrm{Cl}-\mathrm{chl} a$ is proof of the presence of chlorine in these derivatives.

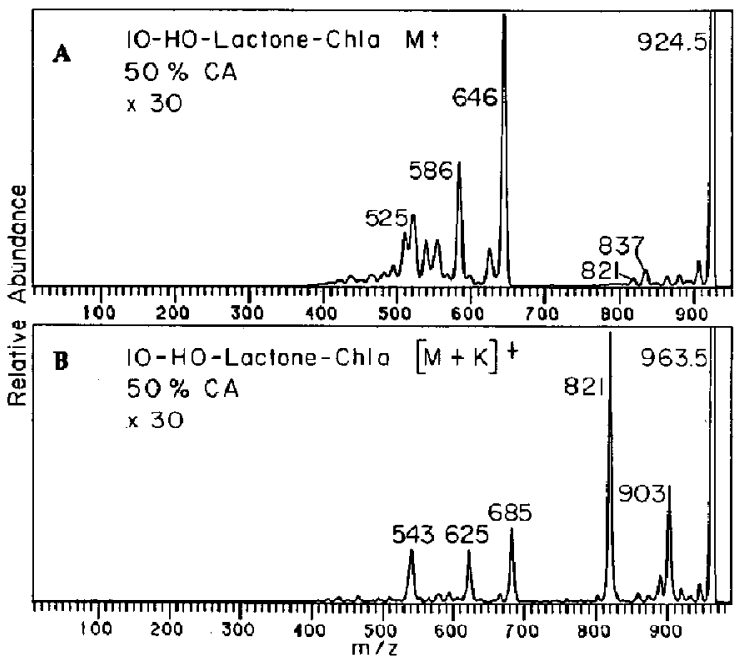

Figure 6. Collisional activation mass spectra of 10-hydroxylactone chl a (a) $\mathrm{M}^{+\cdot}$ ion of $m \sqrt{z} 924.5$ and (b) $[\mathrm{M}+\mathrm{K}]^{+}$inn of $m / z 963.5$.

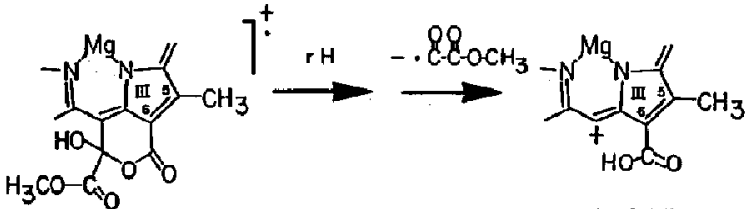

Scheme III

An interesting fragmentation is observed upon CA of 10-hydroxylactone chl 4a. The loss of $87 \mathrm{u}$ from the $\mathrm{M}^{+\cdot}$, not seen for the other chlorophylls, produces the ion of $m / z 837$ (see Figure 6a) and is proposed to be due to the rearrangement of the hemiketal, opening of ring $\mathrm{V}$, and subsequent loss of $\mathrm{C}_{3} \mathrm{H}_{3} \mathrm{O}_{3}$ as shown in Scheme III. This fragment ion is formed in the FAB source as well as upon CA. High-resolution mass analysis of the source-produced ion of $\mathrm{m} / \mathrm{z} 837$ indicates an atomic composition of $\mathrm{C}_{52} \mathrm{H}_{69} \mathrm{~N}_{4} \mathrm{O}_{4} \mathrm{Mg}$ (measured mass within $4 \mathrm{ppm}$ deviation from calculated mass of $837.5169 \mathrm{u}$ ), which is consistent with this structure.

\section{Metastable Decompositions of Chlorophyll a}

Several years ago, considerable attention was given to the extensive fragmentation of chl a produced by ${ }^{252} \mathrm{Cf}$ PDMS [6, 7] and LD [10]. Hunt et al. [6] studied the desorption of chl $a$ from thin films by ${ }^{252} \mathrm{Cf}$-PDMS and concluded that the intense fragmentation is due to high excitation of the desorbed ion triggering an "explosive fragmentation cascade" lasting $10^{-12}-10^{-14} \mathrm{~s}$. Chait and Field [7] also used ${ }^{252} \mathrm{Cf}-\mathrm{PDMS}$ combined with time-of-flight MS, and although they also observed extensive fragmentation (only 1.3\% of the chl $a$ molecular ions survived the $67-\mu \mathrm{s}$ flight to the detector), they concluded that the decompositions were metastable and occurred over a longer time, $10^{-4}-10^{-9} \mathrm{~s}$. The results with the time-of-flight instruments prompted Brown and Wilkins [10] to investigate the applicability of LD/FTMS with its longer detection time scale $\left(>10^{-3} \mathrm{~s}\right)$. Although less fragmentation was observed when chlorophyll samples are laser desorbed from a solid matrix doped with $\mathrm{KBr}$, a substantial amount of fragmentation occurs when chlorophyll samples are desorbed from a laser probe tip without previous addition of the dopant.

In our instrument, molecular ions are collisionally activated in the third FFR. An ion of $\mathrm{m} / \mathrm{z} 893$ accelerated out of the source at $8 \mathrm{kV}$ must survive the flight time of $50 \mu \mathrm{s}$ to the collision cell. If only $2 \%$ of the molecular ions survive the flight to the third FFR, this would seriously hamper the sensitivity of sector instruments for MS/MS studies of chlorophylls.

Considerable decomposition occurs in the FAB source $\left(10^{-7} \mathrm{~s}\right)$ as evidenced by the abundant fragment ions in the full-scan mass spectrum of chl $a$ (Figure 2). It is difficult to measure accurately the fraction of molecular ions decomposing in the source; however, a rough approximation is made by comparing the ion current of the molecular ion region to the total ion current in the full-scan mass spectrum. By considering 
only the portion of the mass spectrum $\geq 400 \mathrm{u}$ (very little fragmentation is evident below $400 \mathrm{u}$ in the CA MIKES spectrum), it is concluded that the molecular ion region ( $m / z$ 890-920) contains $7 \%$ of the total ion current.

Comparison of linked scans at constant $B / E$ and MIKES scans can give at least semiquantitative information about the metastable decompositions occurring in the first FFR (1-3 $\mu \mathrm{s})$ and in the third FFR (44-52 $\mu \mathrm{s})$, respectively. In contrast to the CA spectra, the metastable spectra (Figure 7) are not complicated; the predominant metastable decomposition is the loss of the phytyl group ( $m / z 892.5 \rightarrow m / z 614)$. Integration of the peak areas in the $B / E$ scan (Figure $7 b$ ) indicates that approximately $40 \%$ of the molecular ions that survive acceleration out of the source decompose in the first FFR. In comparison, only $2 \%$ of the molecular ions that survive the flight to the third FFR have sufficient energy to fragment in that region (Figure 7a). Although we propose that the ions produced by FAB are less energetic than those produced by PDMS, these observations reveal that a considerable number of molecular ions do not survive in the 1-3- $\mu$ s time frame. From a practical perspective, detection limits experiments (see below) indicate that a sufficient number of molecular ions are generated by FAB that MS/MS experiments can be run by using as little as $10 \mathrm{pmol}$ of material.

The interpretation of the linked scan data requires a word of caution. The collection efficiencies of the $B / E$ and MIKES scans are considerably different. Only a fraction of the relevant ions are sampled in the linked scan experiments due to the kinetic energy spread of the ions. The actual abundance of metastable decomposition in this region may be higher than what is measured. This effect, however, is counterbalanced by an increase in ion abundance because some $\mathrm{CA}$ may be occurring in the first FFR1. The pressurization of this region is a consequence of the relatively high source pressure used in FAB. The net result of these two factors is that the relative abundance measurement from the linked scan experiment is, at best, a rough estimate.

\section{Collision-Activated Decomposition of $\left[\mathrm{M}+\mathrm{H}^{+}\right.$ Versus $M^{+}$of Chlorophyll a}

In the original MS/MS study, Bricker and Russell [24] reported the CAD of the $[\mathrm{M}+\mathrm{H}]^{+}$of chl $a$ desorbed by FAB from a matrix of ONPOE. The contribution of the ${ }^{13} \mathrm{C}$-containing $\mathrm{M}^{+}$ion to the $[\mathrm{M}+\mathrm{H}]^{+}$ion in their experiment is not clear. In our experiments, of the molecular ions formed by FAB of chl $a$ in ONPOE, $18 \%$ were $[\mathrm{M}+\mathrm{H}]^{+}$ions. A mass resolution of 200,000 $(m / \Delta m)$ is required to separate the $[\mathrm{M}+\mathrm{H}]^{+}$ion from ${ }^{13} \mathrm{C}$-containing $\mathrm{M}^{+}$of $\mathrm{chl} a$, as was mentioned earlier. It is probable that a substantial number of the ions of $\mathrm{m} / \mathrm{z} 893.5$ that were activated in the Bricker and Russell experiment were the ${ }^{13} \mathrm{C}$ isotope of the $\mathrm{M}^{+\cdot}$ ion or that the activated ion was indeed the $\mathrm{M}^{+\cdot}$ ion.

Boyd et al. [25] were also concerned with which precursor ion was used in the Bricker and Russell exper-

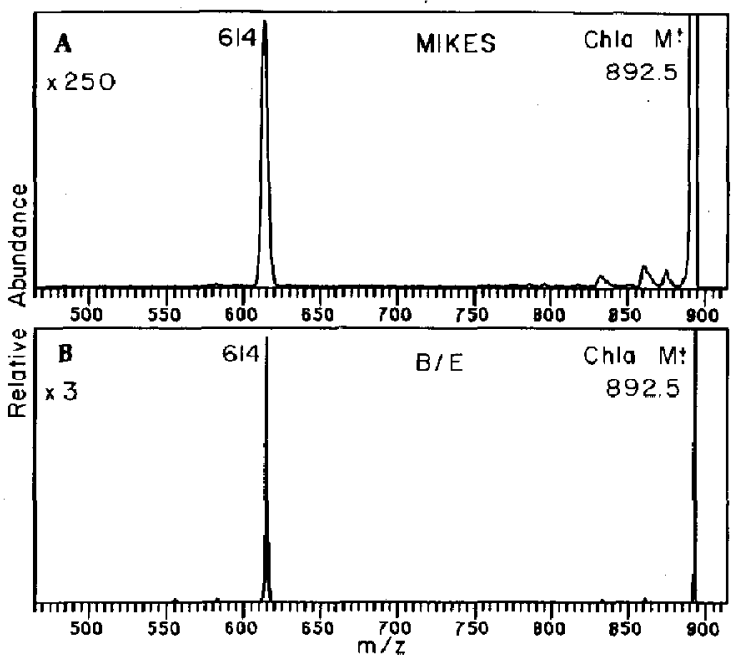

Figure 7. (a) Metastable ion spectrum (MTKES mode) of chl a $\mathrm{M}^{+}$ion of $m / 2892.5$. (b) Metastable ion spectrum (B/E linked mode) of chl $a \mathrm{M}^{+*}$ ion of $\mathrm{m} / \mathrm{z} 892.5$.

iments. They mass-selected and collisionally activated both the chl $a$ ion of $m / z 892.5\left(\mathrm{M}^{+}\right.$all low-mass isotopes) and the ion of $m / z 893.5$ (mixture of $[\mathrm{M}+\mathrm{H}]^{+}$ low-mass isotopes and $\mathrm{M}^{+\cdot}$ containing either one ${ }^{13} \mathrm{C}$ or ${ }^{25} \mathrm{Mg}$ ). They were concerned only with the translational energy loss of the $\mathrm{m} / \mathrm{z} 892.5 \rightarrow \mathrm{m} / \mathrm{z} 614$ (or $m / z 893.5 \rightarrow m / z$ 615) decomposition and concluded that the apparent translational energy shifts are the same regardless of which precursor ion is selected. Only the mass spectrum of fragment ions over the range $m / z 600-630$ was reported.

Because there is a question of which precursor ions were activated in the previous study, we attempted to compare the CAD spectra of the $\mathrm{M}^{+}$and the $[\mathrm{M}+\mathrm{H}]^{+}$ of chl $a$. Figure $3 b$ is the CA mass spectrum of chl a m/z 893.5 ion desorbed for DTT/DTE. Comparison of the isotopic abundance of the molecular ion region with the calculated ratio indicates that this spectrum represents the composite decompositions of a mixture of $50 \%[\mathrm{M}+\mathrm{H}]^{+}, 45 \%{ }^{13} \mathrm{CM}^{+}$, and $5 \%{ }^{13} \mathrm{C}_{2}\left[\mathrm{M}-\mathrm{H}^{+}\right.$ ions. The limited mass resolution of the MIKES experiment does not allow assignment of exact masses to the fragment ions, many of which are seen as unresolved multiplets. Qualitatively, however, the fragment ions from the losses of $\mathrm{CH}_{3} \mathrm{OH}$ and $\mathrm{C}_{2} \mathrm{H}_{4} \mathrm{O}_{2}\left(\mathrm{CH}_{3} \mathrm{OH}+\mathrm{CO}\right)$ are more abundant than in the $\mathrm{M}^{+}$fragmentation. These more abundant fragment ions can be rationalized as being due to more facile losses of methanol and $\mathrm{CO}$ from the enol form of the protonated species (Scheme IV).
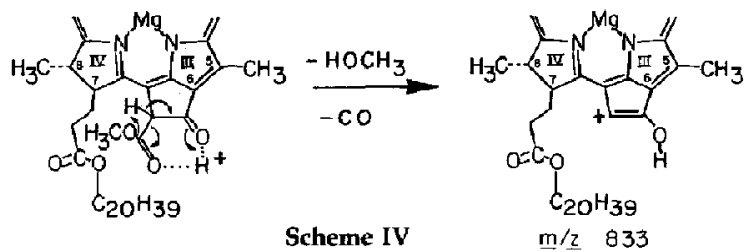
It is noteworthy that the decompositions reported in the Bricker and Russell work more closely match those of the $\mathrm{M}^{+\cdot}$ ion (Figure 3a) than those of the $[\mathrm{M}+\mathrm{H}]^{+}$ ion (Figure $3 \mathrm{~b}$ ) in our experiments. It is reasonable, therefore, to suspect that the molecular species studied in their work was principally the $\mathrm{M}^{+\cdot}$ ion.

\section{Collisional Activation of $\left[\mathrm{M}+\mathrm{Cat}^{+}\right.$of Chlorophylls}

Collisional activation of chlorophylls cationized with alkali metals produces mass spectra that are both complementary to those of the $\mathrm{M}^{+\cdot}$ ion and informative of the site of metal ion attachment. Peripheral metal attachment to pheophytin at ring $\mathrm{V}$ was suggested to occur with enulization of the C-9 carbonyl and additional complexation of the metal ion by the $\beta$-keto ester system at $C-10$ [34]. We observed fragmentations that can be explained by interaction of the metal ion at the site.

Collisional activation of the $\left[\mathrm{M}+\mathrm{Li}^{+}\right.$of chl $a$ (Figure 8a) produces fragment ions similar to those from the $\mathrm{M}^{+}$ion. All product ions contain the lithium metal. A prominent product ion that does not have an analogous ion in the $\mathrm{M}^{+}$spectrum is of $m / z 545$. This product ion, which results from the loss of the phytyl chain and subsequent losses of methanol and $\mathrm{CO}_{2}$, is of low abundance in the metastable ion spectrum. A similar fragment ion was observed in the LD of chl $a$ and $b$ doped with $\mathrm{KBr}[10]$. Collisional activation of chl $a$ cationized with other alkali metal ions produces analogous product ions; however, their relative abundances are influenced by the metal ion used. The abundances of the product ions as a function of the cation used, relative to the ion produced by loss of phytyl, are given in Table 3.

A proposed mechanism for the formation of the ion of m/z 545 produced by CA of chl $a[\mathrm{M}+\mathrm{Li}]^{+}$is given in Scheme V. Results from MS/MS/MS experiments in which the $m / z 621$ fragment ion is produced unambiguously from the $\left[\mathrm{M}+\mathrm{Li}^{+}\right.$ion are consistent with this mechanism. A similar mechanism was proposed for the decomposition of the pheophorbide $c \mathrm{M}^{+}$ion; however, it is not clear whether the product ions originate by electron ionization induced processes or by thermal decompositions [50]. A chlorophyll derivative analogous to this proposed structure was synthesized [51], and a cyclopheophorbide enol was also recently isolated [52].

The above fragmentation does not occur upon CA of $[\mathrm{M}+\mathrm{Li}]^{+}$of the 10-hydroxy chlorophylls because the $\mathrm{C}-10$ hydroxy group prevents the loss of methanol,

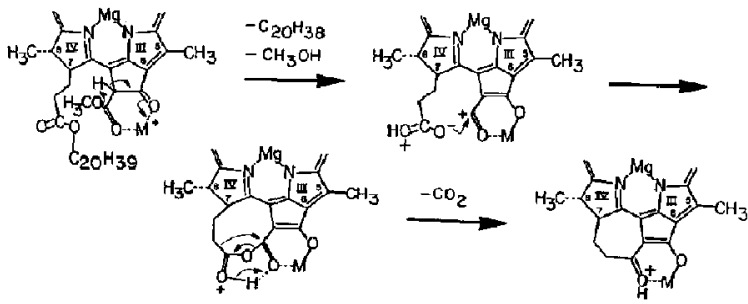

Scheme V m 12 z 545
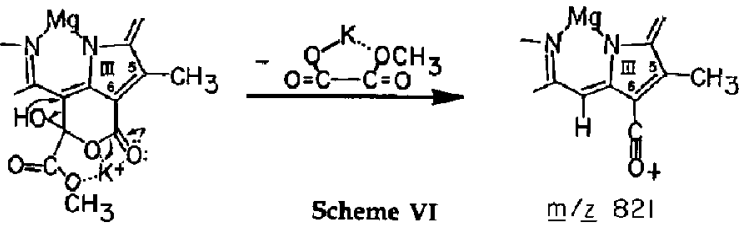

$\underline{\mathrm{m}} / \underline{2} 821$

an observation that is consistent with our mechanism (Figure 8b).

An interesting fragment ion that does not contain the cationizing metal ion occurs upon $\mathrm{CA}$ of the $[\mathrm{M}+\mathrm{Cat}]^{+}$of hydroxylactone chlorophylls. The most abundant ion in the CA spectrum of the $[\mathrm{M}+\mathrm{K}]^{+}$ species of hydroxylactone chl $a$ 4a (Figure $6 \mathrm{~b}$ ) is an ion of $m / z$ 821. This same mass ion is observed in the spectrum of $\left[\mathrm{M}+\mathrm{Cat}^{+}\right.$when the other alkali metal ions are involved and is of low abundance in the $\mathrm{M}^{+}$ CAD spectrum. The metal ion is lost possibly by the mechanism in which the metal ion is chelated by the oxalic acid methyl ester (Scheme VI). Subsequent loss of $m / z 278$ (phytyl) from this ion produces the ion of $m / z$ 543. The relative abundances of the product ions are influenced by the cation used (Table 4). Large losses of $\mathrm{CH}_{3} \mathrm{OH}$ and $\mathrm{CO}$ are observed when the cationization is with $\mathrm{Li}^{+}, \mathrm{Na}^{+}$, and $\mathrm{Cs}^{+}$.

These results point to the analytical utility of using $\mathrm{CA}$ of $[\mathrm{M}+\mathrm{Cat}]^{+}$to distinguish hydroxylactone derivatives easily from other chlorophylts. Methoxylactone chlorophylls, however, do not give this fragmentation; the loss of phytyl gives the most abundant ion upon CA of methoxylactone chl a $\mathbf{4 b}[\mathrm{M}+\mathrm{K}]^{+}$.

\section{Collision-Actionated Decomposition of $\mathrm{M}^{-\cdot}$ of Chlorophylls}

In addition to producing positive ions, FAB of chlorophylls dissolved in 3-NBA causes desorption of negative ions. The molecular ion region of the negative ion mass spectrum of chl $a$ is listed in Table 1 . The predominant desorbed species is the radical anion $\left(\mathrm{M}^{-}\right)$, and a small amount of $[\mathrm{M}-\mathrm{H}]^{-}$is also present. The $\mathrm{CA}$ mass spectrum of chl a $\mathrm{M}^{-}$is presented in Figure 9, and proposed structures of the fragment ions are listed in Table 5. Decompositions can be explained by losses of radicals or neutrals from the radical anion. Possible mechanisms for the formation of the abundant ions of $\mathrm{m} / \mathrm{z} 613$ and 541 are illustrated in Scheme VII.

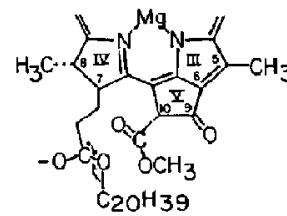
$-\mathrm{C}_{20} \mathrm{H}_{39}$

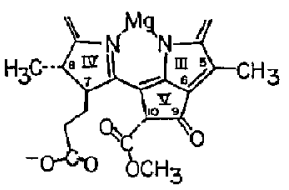

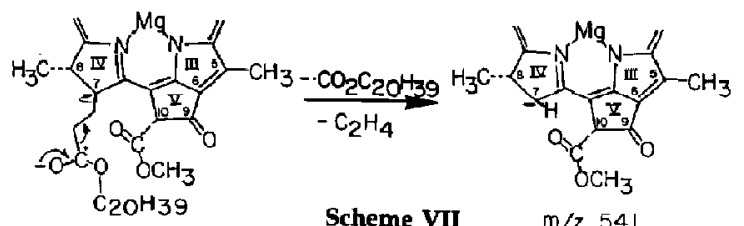




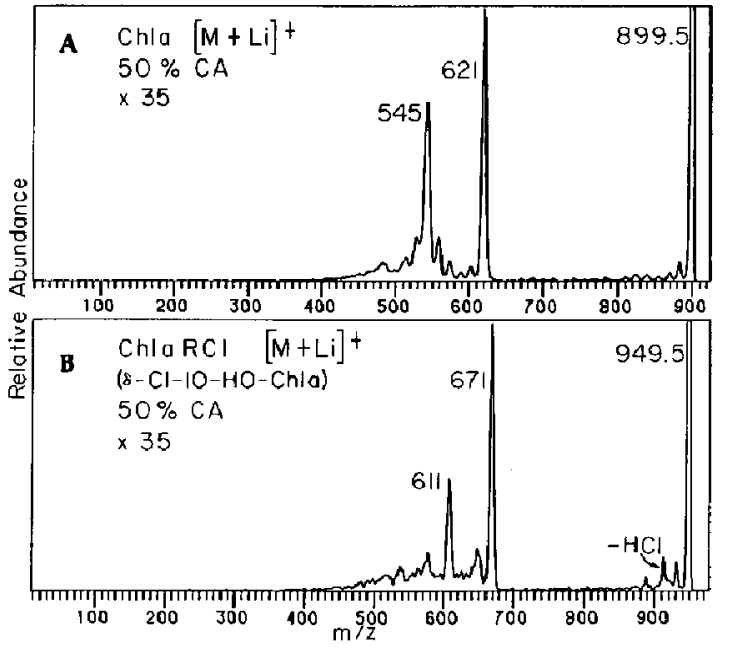

Figure 8. (a) Collisional activation mass spectrum of chl a [M+ $\mathrm{Li}^{+}$ion of $m / 2$ 899.5. (b) Collisional activation mass spectrum of chl $a \mathrm{RCI}(\delta-\mathrm{Cl}-10-\mathrm{OH}-\mathrm{chl} a)[\mathrm{M}+\mathrm{Li}]^{+}$ion of $m i z 949.5$.

The CAD spectra of the $\mathrm{M}^{-}$of the other chlorophylls studied are similar to those of $\operatorname{chl} a$.

\section{Tandem Mass Spectrometry for the Study of Chlorophyll Aggregation}

In addition to giving abundant $\mathrm{M}^{+\cdot}$ ions, $\mathrm{FAB}$ of chl a dissolved in 3-NBA also produces a less abundant dimer $[2 \mathrm{M}]^{+}$, which is observed as a cluster of ions centered at $m / z$ 1787. A comparison of the relative abundances of the individual peaks comprising the molecular cluster with calculated values for an atomic composition of $\mathrm{C}_{110} \mathrm{H}_{144} \mathrm{~N}_{8} \mathrm{O}_{10} \mathrm{Mg}_{2}$ (Table 6) confirms that the ion is dominantly the $[2 \mathrm{M}]^{+}$dimer and not a proton-bound species $[2 \mathrm{M}+\mathrm{H}]^{+}$. Detection of (singly charged) higher oligomers is prevented by the mass range of our instrument $(\sim 1800 \mathrm{u}$ at full accelerating potential). The dimer, trimer, tetramer, etc., of chl $a$ are observed with decreasing abundances when desorbed by ${ }^{252} \mathrm{Cf}$-PDMS [53]. The dimers of chl $b$, bchl $a$, and pheophytin $a$ were also studied.

The CA mass spectrum of the bchl a 3 a dimer of $m / z 1821$ (see Figure 10) demonstrates that mass spectrometry is useful for studying chlorophyll aggregates.

Table 3. Relative abundance of $\left[\mathrm{M}+\mathrm{Cat}-\mathrm{C}_{20} \mathrm{H}_{38}-\right.$ $\mathrm{CH}_{3} \mathrm{OH}-\mathrm{CO}_{2} \mathrm{~J}^{+}$from collisional activation of chlorophyll $a[\mathrm{M}+\mathrm{Cat}]^{+}$ions for various metal ions

\begin{tabular}{lcc}
\hline Metal ion & $m / z$ & Relative abundance* \\
\hline $\mathrm{Li}$ & 545 & 80 \\
$\mathrm{Na}$ & 561 & 111 \\
$\mathrm{~K}$ & 577 & 51 \\
$\mathrm{Rb}$ & 623 & 35 \\
$\mathrm{Cs}$ & 671 & 15
\end{tabular}

- A bundances relative to the $\left[\mathrm{M}+\mathrm{Cat}-\mathrm{C}_{20} \mathrm{H}_{38}\right]^{+\cdot}$ ion.
Table 4. Relative abundance of product ions from collisional activation of hydroxylactone chlorophyll a $\mathrm{M}^{+\cdot}$ and $[\mathrm{M}+\mathrm{Cat}]^{+}$

\begin{tabular}{lrrrrrr}
\hline Product ion & $\mathrm{Li}^{+}$ & $\mathrm{Na}^{+}$ & $\mathrm{K}^{+}$ & $\mathrm{Rb}^{+}$ & $\mathrm{Cs}^{+}$ & $\mathrm{M}^{+}$ \\
\hline $\mathrm{M}-60$ & 100 & 99 & 43 & 47 & 100 & 4 \\
$m / 2821$ & 29 & 100 & 100 & 100 & 92 & 3 \\
$\mathrm{M}-278$ & 81 & 98 & 27 & 26 & 22 & 100 \\
$\mathrm{M}-337$ & 44 & 67 & 19 & 13 & 8 & 45 \\
$m / z 545$ & 11 & 27 & 19 & 8 & 24 & 0 \\
$\mathrm{Cat}^{+}$ & 0 & 0 & 0 & 2 & 5 & - \\
\hline
\end{tabular}

The structure of the bchl $a$ dimer is of considerable interest because of its role as the primary donor $(P)$ in bacterial photosynthesis [27a]. Prior to this study, the molecular ion cluster of the chlorophyll dimers had not been analyzed. Ions of $m / z 910$ and 632 , corresponding to $\mathrm{M}^{+\cdot}$ and $\left[\mathrm{M}-\cdot \mathrm{C}_{20} \mathrm{H}_{38}\right]^{+}$, respectively, are the most abundant ions formed upon $\mathrm{CA}$. The latter ion is probably formed by consecutive decompositions. More revealing are the higher mass ions of $m / z 1789,1762$, and 1543 , due to losses of $\mathrm{CH}_{3} \mathrm{OH}$, . $\mathrm{COOCH}_{3}$, and phytyl from the dimer. The higher mass ions demonstrate that the interaction between the two bchl a molecules is weaker than but comparable to the critical energy for cleaving off the phytyl chain $(17 \mathrm{kcal} / \mathrm{mol})$ [54]. The estimate is based on $\Delta H$ of the reaction $\mathrm{CH}_{3} \mathrm{COOCH}_{2} \mathrm{CH}_{2} \mathrm{CH}_{3} \rightarrow \mathrm{CH}_{3} \mathrm{COOH}+$ $\mathrm{CH}_{2}=\mathrm{CH}-\mathrm{CH}_{3}$, assuming no activation energy and based on $\Delta H_{\mathrm{f} 298}^{\mathrm{D}}(\mathrm{g})$ values.

We propose that the ion of $\mathrm{m} / \mathrm{z} 1189$ from the bchl $a$ dimer results from successive losses of the two phytyl groups and $\mathrm{CH}_{3} \mathrm{OH}$ and $\mathrm{CO}_{2}$ in a mechanism similar to that which occurs upon $\mathrm{CA}$ of the $\left[\mathrm{M}+\mathrm{Cat}^{+}\right.$ species (Scheme V). According to the mechanism proposed in Scheme $V$, the alkali metal ion, chelated by the carbonyl oxygens at $C-9$ and the $\beta$-keto ester, polarizes the carbonyl bond of the ester and thus promotes the nucleophilic attack by the carboxylate oxygen. We suggest that in the bchl $a$ dimer, the $\mathrm{Mg}$ atom of one bchl $a$ molecule interacts with the ring $V$ carbonyl oxygens of the second bchl $a$ molecule similar to the alkali metal ion interaction.

Katz et al. [55] showed experimentally and by ab initio calculations that for chl $a$ dimers the carbonyl at $\mathrm{C} .9$ of ring $\mathrm{V}$ is the favorable site for coordination of

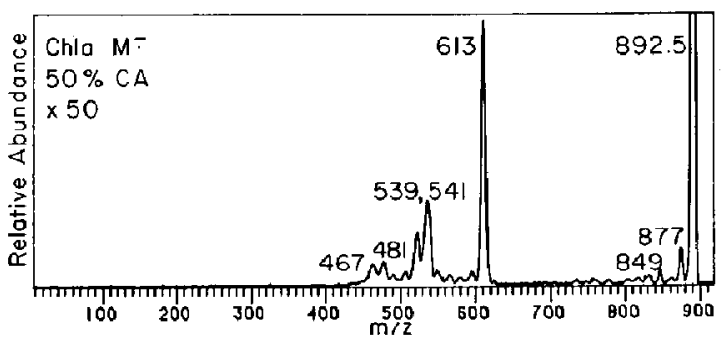

Figure 9. Collisional activation mass spectrum of chl $a \mathrm{M}^{-'}$ ion of $m / z 892.5$. 
Table 5. Collisional activation mass spectrum of chlorophyll $a \mathrm{M}^{+}$

\begin{tabular}{|c|c|c|}
\hline$m / z$ & $\begin{array}{c}\text { Relative } \\
\text { abundance }\end{array}$ & Assignment \\
\hline 892 & & $\mathbf{M}^{--}$ \\
\hline 877 & 12 & {$\left[\mathrm{M}-\cdot \mathrm{CH}_{3}\right]^{-}$} \\
\hline 864 & 2 & {$[\mathrm{M}-\mathrm{CO}]^{\cdots}$} \\
\hline 861 & 2 & {$\left[\mathrm{M}-\cdot \mathrm{OCH}_{3}\right]^{-}$} \\
\hline 849 & 6 & {$\left[\mathrm{M}-\mathrm{CO}-\cdot \mathrm{CH}_{3}\right]^{-}$} \\
\hline 833 & 3 & {$\left[\mathrm{M}-\cdot \mathrm{COOCH}_{3}\right]^{-}$} \\
\hline 613 & 100 & {$\left[\mathrm{M}-\cdot \mathrm{C}_{20} \mathrm{H}_{39}\right]^{-}$} \\
\hline 597 & 5 & {$\left[\mathrm{M}-\cdot \mathrm{C}_{20} \mathrm{H}_{39}-\mathrm{CH}_{4}\right]^{-}$} \\
\hline 595 & 5 & {$\left[\mathrm{M}-\cdot \mathrm{C}_{20} \mathrm{H}_{39}-\mathrm{H}_{2} \mathrm{O}\right]^{-}$} \\
\hline 541 & 30 & {$\left[\mathrm{M}-\cdot \mathrm{C}_{2} \mathrm{H}_{4} \mathrm{CO}_{2} \mathrm{C}_{20} \mathrm{H}_{39}\right]^{-}$} \\
\hline 539 & 33 & {$\left[\mathrm{M}-\cdot \mathrm{C}_{2} \mathrm{H}_{4} \mathrm{CO}_{2} \mathrm{C}_{20} \mathrm{H}_{39}-\mathrm{H}_{2}\right]^{-}$} \\
\hline 525 & 20 & {$\left[\mathrm{M}-\cdot \mathrm{C}_{2} \mathrm{H}_{4} \mathrm{CO}_{2} \mathrm{C}_{20} \mathrm{H}_{39}-\mathrm{CH}_{4}\right]^{-}$} \\
\hline 481 & 10 & {$\left[\mathrm{M}-\cdot \mathrm{C}_{2} \mathrm{H}_{4} \mathrm{CO}_{2} \mathrm{C}_{20} \mathrm{H}_{39}-\mathrm{CO}-\mathrm{HOCH}_{3}\right]^{-}$} \\
\hline 467 & 9 & {$\left[\mathrm{M}-\mathrm{C}_{2} \mathrm{H}_{4} \mathrm{CO}_{2} \mathrm{C}_{20} \mathrm{H}_{39}-\mathrm{CO}-\mathrm{HOCH}_{3}-14\right]^{-}$} \\
\hline
\end{tabular}

the $\mathrm{Mg}$ atom to another chl $a$ molecule, in agreement with our mechanism. This is in contrast to theoretical studies of bchl $a$ that indicate that the preferred arrangement of the dimer is ring I of one monomer over ring $I$ of the other, which allows favorable bonding of the oxygen atoms on the C-2 acetyl groups with the $\mathrm{Mg}$ atoms on the opposite monomeric halves [56].

Dimer formation is not due only to the $\mathrm{C}=\mathrm{O} \cdots \mathrm{Mg}$ bonding. Fast atom bombardment also produces a lowabundance pheophytin $a$ dimer in which the association is a $\pi-\pi$ interaction. The pheophytin $a$ dimer was not observed in ${ }^{252}$ Cf-PDMS experiments [53].

Collisional activation of mixed adducts ("dimers") can be used to order the chlorophylls qualitatively in terms of their ionization potentials. Cooks et al. [57] used a similar method to determine the ordering of gas-phase proton affinities of bases. They determined the relative proton affinities from the metastable and collisionally induced decompositions of proton-bound dimers.

Table 6. Relative abundances of chlorophyll $a$ dimer molecular ion region

\begin{tabular}{lcc}
\hline$m / z$ & Calculated & Experimental \\
\hline 1783 & & 9.8 \\
1784 & & 11.2 \\
1785 & 64.33 & 65.9 \\
1786 & 100.00 & 100 \\
1787 & 95.72 & 87.7 \\
1788 & 66.00 & 61.5 \\
1789 & 35.38 & 32.6 \\
1790 & 15.40 & 14.8 \\
1791 & 5.51 & 5.9 \\
1792 & 1.63 & 3.3 \\
1793 & 0.37 & 1.1 \\
1794 & 0.07 & \\
\hline
\end{tabular}

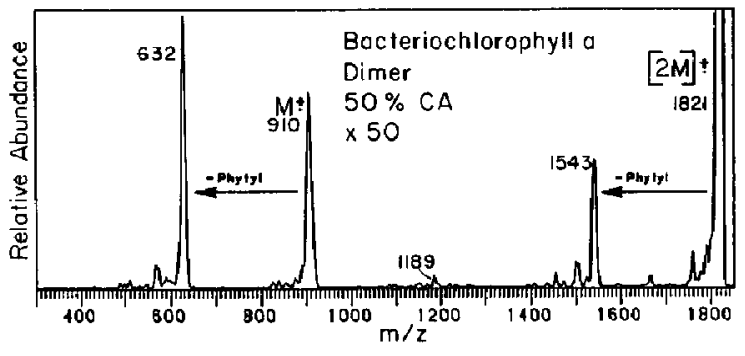

Figure 10. Collisional activation mass spectrum of bchl $a$ dimer $[2 \mathrm{M}]^{+\cdot}$ of $m / z 1821$.

Table 7 lists the relative abundances of the monomer radical cations $\left(\mathrm{M}^{+}\right)$produced by $\mathrm{CA}$ of mixed adducts. These gas-phase adducts were formed by mixing equal amounts of the two components on the probe tip and desorbing with FAB. These experiments position the chlorophylls in order of increasing ionization potentials: bchl $a<\operatorname{chl} a<$ pheophytin $a<\mathrm{chl}$ $b$. These results are consistent with the ordering in terms of solution oxidation potentials, with the exception that in solution chl $b$ has a lower oxidation potential than pheophytin $a[58]$.

\section{Evaluation of Detection Limits for Collision- Activated Decomposition of Chlorophyll a $\mathrm{M}^{+} \cdot$ Ions}

To evaluate the amount of chl $a$ necessary to obtain meaningful MS/MS spectra for the $\mathrm{M}^{+}$ion, varying amounts of a solution of chl $a$ in ether were mixed with 3-NBA on the FAB probe tip and 10 scans were acquired. The concentration of the original (master) solution was determined from Beer's law on the basis of the absorbance at 662 and $428 \mathrm{~nm}$ and published molar absorptivities [59].

When 200,100 , and $50 \mathrm{ng}(200,100$, and $50 \mathrm{pmol})$ of chl a were used, the MS/MS spectra were essentially the same. As the amount of chl $a$ placed on the probe was lowered to 20,10 , and $1 \mathrm{ng}$ (20, 10 , and 1 pmol), there was a significant decrease in main beam and signal-to-noise (S/N) ratio of the CAD mass spectra. The time over which useful spectra could be produced was also significantly reduced as lower amounts

Table 7. Relative abundances of $[\mathrm{M}]^{+-}$from collisional activation of mixed chlorophyll adducts

\begin{tabular}{|c|c|c|c|c|}
\hline Adduct & {$[\mathrm{chl} a]^{++}$} & {$[\operatorname{chl} b]^{+\cdot}$} & {$[b h l a]^{+}$} & {$\left[\begin{array}{lll}\text { pheo } & a\end{array}\right]^{+\cdot}$} \\
\hline$[\mathrm{chl} a \cdots \operatorname{chl} b]^{+}$ & 100 & 45 & & \\
\hline$[\mathrm{chl} a \cdots b c h l a]^{+}$ & 50 & & 100 & \\
\hline 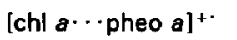 & 100 & & & 56 \\
\hline$[\text { chl } b \cdots b c h l a]^{+}$ & & $20^{*}$ & $100^{*}$ & \\
\hline [chl $b \cdots$ pheo a ] $]^{+}$ & & 38 & & 100 \\
\hline [bchl a $\cdots$ pheo a $]^{+\cdot}$ & & & 100 & 44 \\
\hline
\end{tabular}

* Estimate; mass resolution not sufficient to separate completely [chl $b]^{+\cdot}(m / 2906.5)$ and $[b c h l a]^{+\cdot}(m / 2910.5)$. 
of sample were used; with $1 \mathrm{ng}$, the precursor ion beam was undetectable after 10 scans.

In the spectrum obtained by using $1 \mathrm{ng}$, the $\mathrm{m} / \mathrm{z}$ 614 ion (loss of phytyl) is easily identified; the poor $\mathrm{S} / \mathrm{N}$ ratio ( $\mathrm{S} / \mathrm{N}=3$ ), however, prevents assignment of the less abundant ions. The assignments of most of the ions can be made using as little as $10 \mathrm{ng}$; for identification of the ions resulting from charge-remote fragmentations of the phytyl side chain, $100 \mathrm{ng}(100$ pmol) is needed. These results are similar to those obtained by Brereton et al. [14], who were able to acquire a full-scan FAB spectra with 100 pmol of chlorophyll.

\section{Conclusions}

Fast atom bombardment combined with MS/CA/MS is a useful method for the characterization of chlorophylls. The incorporation of FAB/MS/MS with the various chromatographic and optical spectroscopic methods will provide a powerful arsenal of analytical tools for chlorophyll research. The advantages of structural determination on samples of limited quantities and in mixtures make MS/MS especially attractive. In addition, FAB/MS/MS can be used for investigating the intrinsic reactivity of chlorophyll, such as the gas-phase dimerization of chlorophyll studied in this report.

Collisional activation of chl a $\mathrm{M}^{+\cdot}$ ions produces fragment ions that are consistent with the metastable decomposition of chl a previously reported. Abundant product ions are due to losses of the phytyl chain and the $\beta$-keto group of ring $V$. In addition, previously unreported charge-remote fragmentations of the phytyl chain occur and are useful for identification of branch points on the alkyl chain. The detection limit for obtaining a CA mass spectrum of $\mathrm{M}^{+}$ions of chl $a$ is 10 ng (10 pmol).

Structural modifications of the chlorophyll molecule can be detected by using the CAD mass spectra. For example, the loss of methanol observed upon $\mathrm{CA}$ of chl $a$ is absent from the CA of chlorophyll oxidation products in which the C-10 hydrogen is replaced by a hydroxy group. Although chlorophyll allomers are easily identified by the FAB mass spectra, MS/MS provides additional confirmation. This is especially important for identifying isomers. For example, 10-methoxylactone chl $a$ and 10hydroxylactone chl $b$, which have the same molecular formula $\left(\mathrm{C}_{56} \mathrm{H}_{74} \mathrm{~N}_{4} \mathrm{O}_{7} \mathrm{Mg}\right.$, m/z 938.5), are easily distinguished by $\mathrm{CA}$ of their $[\mathrm{M}+\mathrm{K}]^{+}$ions.

Collisional activation of chlorophylls cationized with alkali metal ions (i.e., $\left[\mathrm{M}+\mathrm{Cat}^{+}{ }^{+}\right.$) produres additional and complementary information. The results are evidence that ring $\mathrm{V}$ in chlorophyll is the principal binding site of additional metal cations.

\section{Acknowledgment}

We are grateful to $R$. Heald for the gift of purified pheophytin a. Preliminary results were presented at the 37th ASMS Conference on Mass Spectrometry and Allied Topics, Miami Beach, Florida, 1989. This work was supported by the Midwest Center for Mass Spectrometry, a National Science Foundation Regional Instrumentation Facility (grant no, CHE-8620177). M. S. was supported by the Studienstiftung des deutschen Volkes.

\section{References}

1. Pelletier, F.; Caventor, J. B. Ann. Chim. Phys. Ser. 2 1818, 9, 194-196.

2. Rebeiz, C. A.; Wu, S. M.; Kuhadja, M.; Daniell, M.; Perkins, E. J. Mol. Cell. Biochem. 1983, 57, 97-125. Leeper, F. J. Nat. Prod. Rep. 1985, 2, 19-47; 1985, 2, 561-580; 1987, 4, 441-469. Kotzabasis, K,; Senger, H. Z. Naturforsch, 1986, 47C, 1001-1003. Kotzabasis, K.; Senger, H. Naturwiss. 1986, 73, 681-682. Kotzabasis, K.; Schüring, M.-P.; Senger, H. Physiologia Plantarum 1989, 75, 221-226.

3. Bazzaz, M. B.; Brereton, R. G. FEBS Lett. 1982, 138, 104-108.

4. Smith, K. M.; Bobe, F. W. J. Chem. Soc. Chem. Comtmtun, 1987, 276-277.

5. Dougherty, R. C.; Driefuss, P. A.; Sphon, J.; Katz, J. J. J. Am. Chem. Soc. 1980, 102, 416-418.

6. Hunt, J. E.; Macfarlane, R, D.; Katz, J. J.; Dougherty, R, C. J. Am. Chem. Soc. 1981, 103, 6775-6778.

7. Chait, B. T, Field, F. H. J. Am. Chem. Soc. 1982, 104, 5519-5521; 1984, 106, 1931-1938.

8. Posthumus, M. A.; Kistemaker, P. G.; Meuzelaar, H. L. C.; Ten Noever de Brauw, M. C. Anal. Chem. 1978, 50, 985-991.

9. Tabet, J.-C.; Jablonski, M.; Cotter, R. J.; Hunt, J. E. Int. J. Mass Spectrom. Ion Processes 1985, 65, 105-117.

10. Brown, R. S.; Wilkins, C. L. J. Am. Chem. Soc. 1986, 108, 2447-2448.

11. Grotemeyer, J.; Boesl, U.; Walter, K.; Schlag, E. W. J. Am. Chem. Soc. 1986, 108, 4233-4234; Org. Mass Spectrom. 1986, 21, 645-653. Grotemeyer, J.; Schlag, E. W. Angew, Chem. Eng. Ed. 1988, 27, 447-592.

12. Constantin, E.; Nakatani, Y.; Teller, G.; Hueber, R.; Ourisson, G. Bull. Soc. Chim. Fr. 1981, 7/8, II303-II305.

13. Barber, M.; Bordoli, R. S.; Eilliott, G. J.; Sedgwick, R. D.; Tyler, A. N. Anal. Chem. 1982, 54, 645A-657A.

14. Brereton, R. G.; Bazzaz, M. B.; Santikarn, S.; Williams, D. H. Tetrahedron Lett. 1983, 24, 5775-5778.

15. Salehpour, M.; Hunt, J. E. Int. J. Mass Spectrom. Ion Processes $1988,85,99-115$.

16. Grese, R. P.; Gross, M. L. J. Am. Soc. Mass Spectrom., submitted.

17. Rinehart, K. L., Jr. Science 1982, 218, 254-260.

18. Gross, M. L.; Jensen, N. J.; Lippstreu-Fisher, D. L.; Tomer, K. B. In Mass Spectrometry in the Health and Life Sciences; Burlingame, A. L.; Castagroli, N., Jr., Eds.; Elsevier: Amsterdam, 1985; pp 209-238.

19. (a) Hunt, D. F.; Bone, W. M.; Shabanowitz, J.; Rhodes, J.; Ballard, J. M. Anal. Chem. 1981, 53, 1704-1706. Hunt, D. F.; Yates, I. R. III; Shabanowitz, J.; Winston, S.; Hauer, C. R. Proc. Natl. Acad. Sci. U.S.A. 1986, 83, 6233-6237. (b) Lippstreu-Fisher, D. L.; Gross, M. L. Anal. Chem. 1985, 57, 1174-1180. (c) Biemann, K.; Martin, S. A. Mass Spectrom. Rev. 1987, 6, 1-76. Biemann, K.: Scoble, H. A. Science 1987, 237. 992-998. Biemann, K. Anal. Chem. 1986, 58, 1288A-1300A. Martin, S. A.; Biemantn, K. Int. J. Mass Spectrom. Ion Processes 1987, 78, 213-228.

20. Adams, J.; Deterding, L. J.; Gross, M. L. Spectrose. Int. J. $1987,5,199-228$.

21. Crow, F. W.; Tomer, K. B.; Gross, M. L.; McCloskey, J. A.; Bergstrom, D. E. Anal. Biochem. 1984, 139, 243-262. Cerny, R. L.; Gross, M. L.; Grotjahn, L. Anal. Biochem. 1986, 156, 424-435.

22. Tomer, K. B.; Gross, M. L. Biomed. Environ. Mass Spectrom. 1988, 15, 89-98.

23. Jackson, A. H. Phil. Trans, R. Suc, Lond. A 1979, 293, 21-37. 
24. Bricker, D. L.; Russell, D. H. J. Am. Chem. Soc. 1986, 108, 6174-6179.

25. Guevremont, R.; Boyd, R. K. Int. J. Mass Spectrom. Ion Processes 1988, 84, 47-67. Alexander, A. J.; Thibault, P.; Boyd, R. K. J. Am. Chem. Soc. in press.

26. (a) Senge, M.; Dörnemann, D.; Senger, H. FEBS Lett. 1986, 234, 215-217. (b) Senge, M.; Senger, H. Photochem. Photobiol. $1988,48,711-717$.

27. (a) Deisenhofer, J.; Epp, O.; Miki, K.; Huber, R.; Michel, $H$. J. Mol. Biol. 1984, 180, 385-398. (b) Norris, J. R.; Uphaus, R. A.; Crespi, H. L.; Katz, J. J, Proc. Natl. Acad. Sci. U.S.A. 1971, 68, 625-628. (c) Shipman, L. L.; Cotton, T. M.; Norris, J. R.; Katz, J. J. Proc. Natl. Acad. Sci. U.S.A, 1976, 73, 1791-1794.

28. Adams, I.; Gross, M. L. I. Am. Chem. Soc. 1986, 108, 6915-6921; Anal. Chem. 1987, 59, 1576-1582.

29. Röllgen, F. W.; Giessmann, U.; Borchers, F.; Levson, K. Org. Mass Spectrom. 1978, 13, 459-461.

30. Weber, R.; Levson, K.; Boerboom, A. J. H.; Haverkamp, J. Int. J. Mass Spectrom. In Phys. 1983, 46, 305-308.

31. Liehr, J. G.; Kingston, E. E.; Beynon, I. H. Biomed. Mass Spectrom. 1985, 12, 95-99.

32. (a) Grese, R. P.; Cerny, R. L.; Gross, M. L. J. Am. Chem. Soc. 1989, 111, 2835-2842. (b) Tang, X.; Ens, W.; Standing, K. G.; Westmore, J. B. Anal. Chem. 1988, 60, 1791-1799. (c) Mallis, L. M.; Russell, D. H. Anal. Chem. 1986, 58, 1076-1080.

33. Tomer, K. B.; Gross, M. L.; Deinzer, M. L. Anal. Chem. 1986, $58,2527-2534$

34. Scheer, H.; Katz, J. J. J. Am. Chem. Soc. 1975, 97, 3273-3275; 1978, 100, 561-571.

35. Senge, M.; Senger, H. Biochim. Biophys. Acta. 1989, 977, 177-186.

36. Pennington, F. C.; Strain, H. H.; Svec, W. A.; Katz, J. J. J Am. Chem. Soc. 1967, 89, 3875-3880.

37. Senge, M.; Struck, A.; Dörnemann, D.; Scheer, H.; Senger, H. Z. Naturforsch. 1988, 43C, 515-518.

38. Lötjönen, S.; Hynninen, P. H. Synthesis 1983, 700-711.

39. Gross, M. L.; Chess, E. K.; Lyon, P. A.; Crow, F. W.; Evans, S.; Tudge, H. Int. J. Mass Spectrom. Ion Phys. 1982, 42, 243-254.

40. Burinsky, D. J.; Cooks, R. G.,; Chess, E. K.; Gross, M. L. Anal. Chem. 1982, 54, 295-299.
41. Waterton, J. C.; Sanders, J. K. M. I. Am. Chem. Soc. 1978, $100,4044-4049$.

42. Hunt, J. E.; Schaber, P. M.; Michalski, T, J,; Dougherty, R. C.; Katz, J, J. Int. J. Mass Spectrom. Ion Phys. 1983, 53, 45-58.

43. Schaber, P. M.; Hunt, J. E.; Fries, R,; Katz, J. J. I. Chromatogr. 1984, 316, 25-41.

44. Neumann, G. M,; Derrick, P. J. Org. Mass Spectrom. 1984, 19, $165-170$.

45. Cooks, R. G. In Collisional Spectroscopy; Cooks, R. G., Ed.; Plenum: New York, 1978; pp 357-450.

46. Jensen, N. J.; Tomer, K. B.; Gross, M. L. I. Am. Chem. Soc. $1985,107,1863-1868$.

47. Deterding, L. J.; Gross, M. L. Anal. Chim. Acta 1987, 200, 431-445.

48. McCarthy, S. A.; Belanger, F. C.; Rebeiz, C. A. Biochemistry $1981,200,5080.5087$.

49. Jackson, A. H.; Kenner, G. W.; Smith, K. M.; Aplin, R. T.; Budzikiewicz, H.; Djerassi, C. Tetrahedron 1965, 21 , 2913-2924.

50. Dougherty, R. C.; Strain, H. H.; Svec, W. A.; Uphaus, R. A.; Katz, J. J. J. Am. Chem. Soc. 1970, 92, 2826-2833.

51. Falk, H.; Hoornaert, G.; Isenring, H.-P.; Eschenmoser, A. Helv. Chim. Acta 1975, 58, 2347-2357.

52. Karuso, P.; Bergquist, P. R.; Buckleton, J. S.; Cambie, R. C.; Clark, G. R.; Rickard, C. E. F. Tetrahedron Lett. 1986, 27, $2177-2178$

53. Hunt, J. E.; Macfarlane, R. D.; Katz, J. J.; Dougherty, R. C. Proc. Natl. Acad. Sci. U.S.A. 1980, 77, 1745-1748.

54. Rosenstock, H. M.; Draxl, K.; Steiner, B. W.; Herron, J. T. J. Phys. Chem. Ref. Data 1977, 6 Suppl. 1, I774-1782.

55. Katz, J. J.; Shipman, L. L.; Cotton, T. M.; Janson, T. R. In The Porphyrins; Dolphin, D., Ed.; Academic: New York, 1978; Vol. 5, Part C, pp 401-458.

56. Plato, M.; Tränkle, E.; Lubitz, W.; Lendzian, F.; Möbius, K. Chem. Phys. 1986, 107, 185-196.

57. Cooks, R. G.; Kruger, T. L. I. Am. Chem. Soc. 1977, 99, 1279-1281. McLuckey, S. A.; Cameron, D.; Cooks, R. G. J. Am. Chem. Soc, 1981, 103, 1313-1317.

58. Stanienda, A. Z. Phys. Chem. 1965, 229, 257-272.

59. Strain, H. H.; Thomas, M. R.; Katz, J. J. Biochim. Biophys. Acta 1963, 75, 306-311. 